\title{
"What Was It Like to Learn English?" Learner Interviews in TESL Training
}

Linda Bebout

To help the students in my introductory TESL course learn about the backgrounds and experiences of ESL learners like those they might someday teach, I have each TESL student find and interview a nonnative speaker of English in the community. They ask a variety of questions about the learners' English-language history, such as when they began learning English, whether they received formal ESL instruction, and what it feels like to live and work in a new language. They then write a report of their interview and share their information with the other TESL students in the class. Through this assignment, they gain vivid and valuable insights into both positive and negative aspects of second-language learning, the diversity of paths an immigrant can take to learning English, and the real people behind the abstractions in their textbooks.

Dans le but d'aider les étudiants dans mon cours d'introduction à l'enseignement de l'ALS à comprendre le vécu des gens à qui ils pourraient un jour enseigner l'anglais, des apprenants en ALS, je leur demande de trouver dans la communauté un allophone et de lui faire passer une entrevue. Les étudiants lui posent diverses questions sur l'apprentissage de l'anglais (quand il a commencé, s'il a suivi des cours $d^{\prime} A L S$, comment se passe l'expérience de vivre et de travailler. dans une langue étrangère). A partir de l'entrevue, les étudiants rédigent un rapport et partagent leurs résultats avec les autres étudiants d'ALS en classe. Ce projet fournit aux étudiants des connaissances importantes sur les aspects positifs et négatifs de l'apprentissage d'une langue seconde, sur la diversité de voies que peut adopter un immigrant pour apprendre l'anglais et sur les êtres humains qui se dessinent derrière les abstractions dans leurs manuels de cours.

Most of the students who enroll in my introductory TESL course have had informal contact with nonnative speakers of English: store clerks, coworkers, family members, fellow students, or professors. However, hardly any of the students know much about how their own language works or what goes on in an ESL classroom; few know the backgrounds of the nonnative speakers they have met; and even fewer know anything about how it feels to learn to live one's daily life in a new language and culture. Because all these types of knowledge seem to me to be essential for an ESL teacher, I wish to provide the students in this initial course with at least a foundation in all of these areas. It is relatively easy to give them a start in the first two 
areas mentioned (how the English language works and ESL classroom procedures) by means of textbooks, videos, and lectures. The other two areas (concerning ESL learners' lives) are more of a challenge. To address this challenge, I assign a task that involves direct contact with nonnative speakers, which gives the trainees vivid, practical information about the kind of people they will encounter in their ESL classrooms.

Other ESL teacher trainers have noted the importance of providing opportunities for direct contact between teacher trainees and adult ESL learners. Gray (1998) suggests that practice teachers communicate with their adult ESL students through "interactive diaries," where the ESL students give their novice teachers ongoing feedback about their teaching. Cray and Currie (1996) also encourage the use of written dialogues between beginning TESL trainees and current ESL students, and they employ an interview assignment similar to that described in this article. However, their trainees are allowed to interview a learner of any second language (not just English), and they generate their own interview questions, which seems to result in relatively more emphasis on language instruction issues than does my assignment.

The assignment described below, a focused interview with a nonnative speaker now living in an English-speaking community, is undertaken by the students as part of their first contact with the field of TESL before most of them have even seen an ESL classroom. This provides a chance early in their training for the TESL students to see the anonymous and abstract ESL learners who are referred to in their course materials as complex individuals with lives beyond the ESL classroom.

\section{The Interviewees}

The TESL trainees are instructed to find "someone who is learning (or can remember a lot about learning) English as a second language." The interviewees can be any age at the time of the interview, as long as they began learning English after early childhood (after age 10 or 12). This latter restriction is imposed because I wish the trainees to interview people who are able to recall their experiences from a relatively mature viewpoint and who began to acquire English well after the age when second-language learning is usually an automatic, unconscious process. The current English level of the interviewees is unimportant as long as they are able to understand and respond to the questions. If the trainee speaks the first language of the interviewee, the interview can be conducted all or partly in that language. There is occasionally a student in the TESL course who learned English as a second language beginning in adolescence; such students are allowed to "interview" themselves if they wish, and they have consistently shown excellent insights about their own acquisition. For example, a student who is a native speaker of Croatian wrote: 
One day a year or so ago I caught myself actually THINKING in English. This caused an identity crisis at first but eventually I dissociated my language use from my identity and found that thinking in more than one language is very beneficial to the opinion forming process.

The interviewees found by my ESL teacher trainees come from a variety of sources. Because the immigrant population of the area is large, many students are able to interview family members or members of their own ethnic community. Touching interview reports frequently come from students writing about the linguistic struggles of their own parents, grandparents, or even spouses, who may tell them stories that they had not heard until they did this assignment. A woman who interviewed her Hungarian-born husband told me that she had simply never thought to ask him about his language-learning experiences because they were too busy raising their family. Two students, of Macedonian and Portuguese backgrounds, recounted personal anecdotes:

When my mother was in labor with me ... she could not understand what [the nurses] were telling her. What they were saying was "push, push." These stories are humorous today, but at the time they were traumatic.

One day I came home from school swearing to my heart's content, so [my father] tells me.... He was upset but unable to tell me why it was wrong to say those words. He explained that still to this day he wishes it had been a moment for a good heart-to-heart conversation. He felt ashamed that he could not find the right words to say.

Some trainees who do not already have appropriate immigrant contacts find their interviewees by searching out likely groups of nonnative speakers, for example, in ethnic retirement residences or ESL courses at the YMCA. Others approach a co-worker, a neighbor, or even a clerk at the corner store, and they often report that interviewees say they feel honored to be asked to tell their story.

\section{Interview Questions}

The questions below are given to the TESL students as suggested interview topics. However, the students are encouraged to add other questions of their own, permitted to omit questions that seem inappropriate, and warned that they will probably need to reword many of the questions to make them comprehensible to their interviewees.

1. At what age did your interviewee begin learning English? Why did she or he need/want to learn English? 
2. In what circumstances did she or he learn English (e.g., in school, on the job, in an English-speaking country or elsewhere, from friends)? If in school, what and how was she or he taught? Does she or he think the school experience could have been improved (e.g., different teaching practices)?

3. What does she or he remember about the experience of learning English? Are there any anecdotes she or he can tell (humorous or otherwise) about learning English? How does it feel to try to communicate in a foreign language?

4. What are the rewards and the frustrations of learning a second language? Is it better to be bilingual/multilingual or to be monolingual?

\section{Report Format}

The interview is written as an oral history (rather than in a question-andanswer format). Some biographical information is included, but students are advised not to get so involved in the story of the interviewee's life that they forget to write primarily about their language-learning experiences. For my course, the assigned length of the report is about 1,000 words, but the length could be adjusted to fit the circumstances. For example, trainees could be required to interview more than one person and write a longer report comparing the experiences of their interviewees.

In addition to the information and insights the students receive from their own interviewees, they hear something about their classmates' interviews. During the class meeting where the interview assignments are handed back, the students divide into groups of five or six and take turns telling their group the stories of their interviewees. The groups are also given the task of finding some similarities and differences among their interviewees' experiences, which a representative of each group reports to the whole class at the end of the session. This sharing session ensures that the students gain a better picture of the diversity of the ESL learner population.

\section{Outcomes}

Most students' papers are not dry reports of the interviewees' steps toward acquiring English. In addition to hearing linguistic success stories, the trainees also find out some of the difficulties and negative aspects of secondlanguage learning. This can give them a necessary dose of reality concerning the prognosis for adult second-language learners and the tensions that are an inevitable element in the second-language learning experience.

Learning a second language had affected [Denise's] personality. She had always been an outspoken person.... Suddenly, she was afraid of speaking and would stay in the background.

John noticed that his [Greek immigrant] parents were often dismissed as being ignorant [by Canadian] shop owners and service people. 
One of Mr. Mantler's regrets about his limited English is that he was never able to help his children with their homework.

At parties and larger social gatherings he couldn't stay for more than an hour. He found that a large group of people all speaking English at the same time was overwhelming.

For more than a year at Sacred Heart [School], Yan Shan would continue to have no idea what anyone else was saying. Only when math was the topic could he understand the lessons being taught. Even during math lessons, though, he would refuse to answer any oral questions because no one could understand his pronunciation of numbers.

[Paul] confided that if he had known then what he knows now, and if he had had any choice in the matter, he never would have come to Canada. He never imagined [learning English] would be as hard as it was.

The questions about the interviewees' ESL education experiences open the students' eyes to the diversity of paths an immigrant can take to learning English.

The longing to know English led my [26-year-old] father to St. Clair College to enroll in an English as a second-language course. The six-month course allowed my father to feel more comfortable with his surroundings.... Even though he knew he was not a dummy, [in Canada] he felt like one. His peers [in the class] were in the same situation as he was, so that was his support base.

During the course of a year, [my father] made three separate attempts to go to school; however, because of his work schedule, he ... eventually dropped out completely.

[Rudy] learned primarily through listening and watching [because] there were no schools where he could go to learn the English language.

They also gain valuable insights for their future teaching careers as they hear the interviewees' opinions about teaching methods.

The teacher would draw a picture on the blackboard, write the word under it, and everyone would repeat it. They learned individual words as opposed to sentences. Going to [the ESL night course] was not a valuable experience, since Gizella wanted to learn how to communicate, not just to spell [individual] words.

No language other than English was permitted once inside the class room and " $G$ " felt that this particular rule helped her learning immensely. 
[My dad] could work with words on paper quite well, conjugate just about any verb given to him, and recognize the various tenses in selected sentences, but the speed with which it was necessary to carry on a conversation was completely beyond him. There was no time in speaking with someone to stop, conjugate the verb required, and put the correct form in the sentence.

Finally, they learn something that can be easy to lose sight of in a teacher training program: that most interviewees consider factors outside formal English classes to have been the most helpful in their acquisition of English:

It was also through these friends [a Scottish and an Irish immigrant], and later her children, that she began writing in English for the first time. She would write a letter and give it to one of her friends who would go over it with her, making sure the intended meaning of it was accurate.

He would walk the streets and through department stores, listening to people speak the language while paying attention to what specific action juxtaposed [sic] their speech. He would listen to the radio and try to pronounce the words in newspaper articles.

Surprisingly, it was daytime soap operas that taught her about slang and rhetoric. By watching each day the unfolding consequences of the characters' actions, and listening to their words, she understood the underlying meanings.

\section{Conclusion}

Learning a second language well enough to live one's life in that language is not like learning accounting, geography, or auto mechanics-language is too much a part of one's identity to be learned or taught as a tidy package of subject matter. TESL trainees are likely to encounter this concept in theory, but they also need to see the reality behind the theory, to perceive the multiple ways in which a learner's life and languages are intertwined. By interviewing one nonnative speaker and hearing the stories of others, the beginning TESL trainee finds out about some of the complexities in the lives of ESL learners that might not be immediately visible in education textbooks or even in large classrooms of ESL students.

Also, many native speakers who have had only incidental contact with nonnative speakers have trouble seeing beyond the "otherness" of the immigrants; an assignment like this counteracts this tendency, both through the personal information obtained in the interview and through the act of interviewing. For those students in the class who have already had closer, more extensive contact with immigrants, the assignment gives them the chance to 
learn more about the profound emotions and memories that are connected with second-language learning experiences for immigrants.

Potential ESL teachers are often attracted to the field by the prospect of helping people. I believe that an assignment such as this, completed at the beginning of their training, can help them to establish and maintain a focus on the learner as a whole, complex person: a focus that will serve them well throughout their careers.

\section{The Author}

Linda Bebout has a doctorate in linguistics from Cornell University and an MSc in communication disorders from San Francisco State University. She teaches linguistics, ESL, TESL, and psycholinguistics in the Department of English Language, Literature, and Creative Writing at the University of Windsor. Her research interests include the use of peer tutors in university ESL courses, gendered language in popular culture, and the influence of electronic communication on written language.

\section{References}

Cray, E., \& Currie, P. (1996). Linking adult learners with the education of L2 teachers. TESOL Quarterly, 30, 113-130.

Gray, J. (1998). The language learner as teacher: the use of interactive diaries in teacher training. ELT Journal, 52, 29-37. 